\title{
Design Lighting Quality Based on DIALux Evo 8.1
}

\author{
R. Febriyursandi ${ }^{l}$, A. Z. Azryenni , ${ }^{l}$ A. Hamzah ${ }^{l}$ \\ ${ }^{I}$ Department of Electrical Engineering Engineering, University of Riau, Indonesian \\ Email:azriyenni@eng.unri.ac.id; riski.febriyursandi@student.unri.ac.id
}

\begin{abstract}
This research develops and implements methods for calculating lighting systems for classrooms in the Khairul Ummah Boarding School. The lumen is used to determine the number of luminaires needed to improve lighting quality following SNI 6197:2011. The number of luminaires obtained from this study was entered into the DIALux Evo 8.1 software. The results obtained of this study indicate that the lighting in the classroom at Khairul Ummah Boarding School didn't reach the recommended standard, the direct measurement results of the average lighting level of class A was 10.79 lux, while the class X-IPA-3 was 11.66 lux. To improve this condition, class A requires 15 luminaires, and XIPA-3 requires 12 luminaires. The difference in the results obtained from the two calculations for class $\mathrm{A}$ is $0.6 \%$, and $\mathrm{X}$-IPA-3 is 3.4\%. Investment costs are needed to improve the lighting system in these classes worth Rp.2,700,000.00 to provide 27 lamps.
\end{abstract}

Keywords : Lighting, Lumen Method, DIALux Evo 8.1, Investment Cost

Paper type Research paper

\section{INTRODUCTION}

The classroom is one of the spaces that have an essential function in a formal educational institution. Teachers and students interact in the process of teaching activities in the school. Not only as a place to receive knowledge, but classrooms are also used by students in the process of discussion or just used as a place to relieve fatigue during break time. So that most student activities are carried out in the classroom and indirectly the time spent by student is quite a lot [1]. Education is generally carried out during the day-time but differs from some educational institutions based on the scope of the Islamic boarding school, where training is also carried out at night-time. The availability of lights as a function of supporting the sustainability of activities in the classroom is essential. Lack of concern for the lighting system in the school affects the quality of education at the school. Artificial lighting must be seen in terms of quality and quantity. Artificial meaning is not just providing light, but more than that, lighting can form the atmosphere in space. Lighting is not only a practical problem but also an aesthetic problem. Based on this point of view, the choice of shape, type of lamp and position of placement can be a job that contains element of fun [2]. Lighting quality is influenced by the lights available as a function of supporting the activities in the classroom.

Low lighting quality will hurt the user of the room, the result of which is caused by the low lighting quality such as fatigue in the visual function, disrupting the concentration of the use of the room and even giving effect to the eye becoming short-sighted. Research related to lighting system indoor has been carried out by Rohadi, et al. in 2017 with the title of the article "Test Effectiveness of lecture room lighting using calculux indoor 4.12 software". The research used DIALux 4.12 software to design the lighting system in the C410 lecture room at the UNNES postgraduate building. Direct measurement results state that the existing lighting system doesn't reach the expected standard and based on the results of improvements, to achieve a minimum standard lighting level requires 12 luminaires [2]. Setyaningsih, et al. in 2014 in their journal entitled "Performance of LED light Installed on DKI Jakarta Streets." This research discusses the outdoor lighting system. The results of this study indicate that LED lamps are not suitable to be implemented directly with existing light poles and the spacing specifications of the lamppost and the lack of planning in adjusting the spacing of light posts that varies between 40 meters to 52 meters [3]. Based on problems and related research, then to improve lighting quality, this study will design lighting systems in classrooms based on established standards using two calculation methods, namely the lumen method as a manual lighting calculation and the DIALux Evo 8.1 as software. The lighting calculation simulation illustrates two space scenarios as the research object, including one classroom at MTs Khairul Ummah Islamic Boarding School and one classroom at MA PP Khairul Ummah Islamic Boarding School, this study is titled as "Design And Analysis Lighting Quality Based On DIALux Evo 8.1 Software".

\section{Lighting}

Human recognizes an object visually required good lighting. In general, school is formal educational institutions. The classroom is one of many rooms that has an essential role in the learning and teaching process. Classes are also used by the student to carry out their activities. Lighting has a supporting role in the implementation of student activities. Low lighting levels, high or that cause glare will have an influence on eye health that will cause to become tired. 


\section{Lighting Scale}

a. Luminous flux

Luminous flux emitted by a light source is all light emitted in every second [2]. The unit of luminous flux is lumen ( $1 \mathrm{~m})$, and the luminous flux is expressed by equation 1 [3].

$$
\Phi=\frac{Q}{t}
$$

where:

$\Phi=$ Luminous flux (lumen)

$\mathrm{Q} \quad=$ Light Energy $(\mathrm{lm} . \mathrm{sec})$

$t=$ Time (second)

b. Luminous Intensity

Luminous Intensity is the strength of the light source and is measured by candela [3] and expressed by equation 2 [4].

$$
I=\frac{\Phi}{\omega}
$$

where:

I = Luminous Intensity (candela)

$\Phi=$ Luminous Flux (lumen)

$\omega=$ Room angle (steradian)

c. Illuminance

Illuminance or lighting intensity is the flux of light falling on a surface plane. This unit of illuminance is lumens $/ \mathrm{m}^{2}$ or lux. To calculate the average illumination value expressed by equation 3 [3].

$$
\mathrm{E}=\frac{\Phi}{A}
$$

where:

$\mathrm{E} \quad=$ Illuminance (lux or Lumen/meter)

$\Phi=$ Luminous Flux (lumen)

A $=$ Surface area $\left(\mathrm{m}^{2}\right)$

d. Luminance

Luminance is a measure for the light of an object's surface. To calculate the luminance expressed by equation 4 [3].

$$
\mathrm{L}=\frac{\mathbb{I}}{\mathrm{A}}
$$

where:

$\mathrm{L}=$ Luminance $\left(\right.$ Candela $\left./ \mathrm{cm}^{2}\right)$

$\mathrm{I}=$ Luminous Intensity (Candela)

A $=$ Surface area $\left(\mathrm{m}^{2}\right)$

\section{Lighting Criteria}

There are two places that will be illuminated by the lighting system, namely: Indoor lighting system, and Outdoor lighting system.

\section{Electric Lights and Characteristics}

Artificial lighting has various types and shapes, including:

1. Incandescent Lamp Incandescent lamp is a type of lamp that operated by heating the filament contained therein in high-temperature conditions to produce light.

2. Fluorescent Lamp

This type of lamp is a lamp that is commonly used by the public. This lampwork by producing ultraviolet (UV) radiation at low mercury vapor pressure.

3. High-Intensity Discharge (HID) Lamp

The light produced in this HID lamp is the result of electrical discharge through a metal vapor. To provide optimum light, it takes 3 to 8 minutes.

4. Light Emitting Diode (LED) Lamp

LED lights are the latest developments in the types of lights this time. Tu's kind of lamp has a much longer service life than previous kinds of bulbs. The average age of this lamp is up to 40,000 hours. 


\section{Recommended Minimum Lighting Level}

This lighting standard setting is made in order to facilitate the parties involved in the design of lighting systems. In Table 1 is the recommended minimum lighting level, the lighting should not be less than the specified lighting level.

Table 1 Recommended Lighting Level [4]

\begin{tabular}{cc}
\hline Room Function & Lighting Level (lux) \\
\hline Classroom & 350 \\
Library & 300 \\
Laboratory & 500 \\
Computer Practice room & 500 \\
Language Laboratory room & 300 \\
Teacher's room & 300 \\
Sport room & 300 \\
Image room & 750 \\
Canteen & $\underline{200}$ \\
\hline
\end{tabular}

\section{Lighting Calculation}

To determine the desired number of luminaires or light points, calculations using the lumens method can be carried out. This lumens method is used to calculate the intensity of lighting on the surface area. The calculation procedure uses the lumen method as follows.

a.Determine the index of room (IR) [5]

The index of the room is the ratio between the size of a square-shape space. To calculate the index of the room expressed by equation 5 [5].

$$
\mathbb{R}=\frac{p \times l}{h(p+l)}
$$

where:

$$
\begin{aligned}
p= & \text { Room length (meter) } \\
l= & \text { Room width (meter) } \\
h= & \text { The high light source from the work surface } \\
& \text { (meter) }
\end{aligned}
$$

b. Determine the Utilization Factor (UF)

The utilization factor (UF) value can be seen from the table issued by the relevant lighting manufacture or handbook. c.Determine the Maintenance Factor (MF)

The value of the maintenance factor is influenced by the surrounding environment and the technical element of the lamp in question. In this article, the maintenance factor value is taken as 0.8 .

d. Calculate the number of luminaires

To get the name of luminaires needed by room, then expressed by equation 6 [3].

$$
\mathrm{N}=\frac{E \times A}{L \times U F \times M F}
$$

where:

$\mathrm{N}=$ The Number of the luminaire

$\mathrm{E}=$ Lighting level target (lux)

A $=$ Surface area $\left(\mathrm{m}^{2}\right)$

$\mathrm{L}=$ Total initial lumens of light (lumen)

UF $=$ Utilization Factor

$\mathrm{MF}=$ Maintenance Factor

\section{METHOD}

In this article, the study was conducted using data from the measurement results at the research location. This study took the object of space in class A MTs Khairul Ummah Islamic Boarding School and class B MA Khairul Ummah Islamic Boarding School.

Before taking the data needed as material in this study, we need to determine the necessary parameters such as the size of the room and the shape of the room (length, width, and height), then the number of light point per room, power output (watt) and luminous flux (lumens) produced by each lamp in the place, the type of bulb used in the classroom. 
Then, the next process that needs to be done is to check the lighting level by making direct measurements. In this measurement, the authors use the standards 16-7062-2004 about measuring the intensity of lighting at workplaces. If the result of direct measurement gets value below the minimum standard recommended, it needs to be calculated by updating the type of lamp, the amount of power (watt), and luminous flux (lumens)produced by the light used to improve the quality of the lighting.

Calculation to get the number of luminaires needed to reach the minimum standard determined using the lumen method, where data that have been obtained previously entered into the index of room equation, determine the value of reflecting surface (ceilings, walls and work plan), amount of Utilization Factor (UF) and cost of Maintenance Factor (MF). The next process is to input the value of the calculated equation and the specified value into the final equation to get the number of luminaires needed. After going through a mathematical calculation process using the lumen method, the next process is designing the room using the software used in this study. If the simulation results on the software do not reach the minimum recommended standard, it is necessary to double-check the design made.

After the direct measurement process, recalculation and design of the room in the software are obtained, the next step is to analyze the result obtained from the procedures that have been implemented. In improving the quality of the lighting system, of course, the value of the investment must be included.

\section{DISCUSSION}

This sub-chapter explains the result of the direct measurement of lighting level, calculate the number of luminaires needed, and designs the room and the last calculate the costs required to improve previous conditions.

\section{Direct Measurement}

Direct measurement was made at sunset condition in the classroom A MTs Khairul Ummah Islamic Boarding School and classroom B MA Khairul Ummah Islamic Boarding School. Table 2 is the result of the direct measurement of lighting levels in the two rooms.

Based on the results of the direct measurements, the lighting levels in two rooms have not reached the minimum recommended standard, where the minimum standard lighting level for educational institutions, especially in classrooms is 350 lux. After finding out that the two-room has not yet reached the rule, an improvement is made by recalculating.

Lighting levels that do not reach the standard are caused by the use of a type of lamp that has small luminous flux, and the number of luminaires available to fill the space is small.

Table 2 Direct Measurement Lighting Level Result

\begin{tabular}{ccc}
\hline \multirow{2}{*}{ Point } & \multicolumn{2}{c}{ Classroom } \\
\cline { 2 - 3 } & A & B \\
\hline 1 & $1.90 \operatorname{lux}$ & $1.70 \operatorname{lux}$ \\
2 & $6.70 \operatorname{lux}$ & $8.60 \operatorname{lux}$ \\
3 & $8.60 \operatorname{lux}$ & $17.6 \operatorname{lux}$ \\
4 & $3.20 \operatorname{lux}$ & $10.6 \operatorname{lux}$ \\
5 & $11.1 \operatorname{lux}$ & $4.20 \operatorname{lux}$ \\
6 & $16.4 \operatorname{lux}$ & $11.6 \operatorname{lux}$ \\
7 & $15.8 \operatorname{lux}$ & $25.8 \operatorname{lux}$ \\
8 & $7.70 \operatorname{lux}$ & $12.8 \operatorname{lux}$ \\
9 & $14.2 \operatorname{lux}$ & $3.60 \operatorname{lux}$ \\
10 & $22.0 \operatorname{lux}$ & $11.8 \operatorname{lux}$ \\
11 & $19.8 \operatorname{lux}$ & $28.0 \operatorname{lux}$ \\
12 & $11.0 \operatorname{lux}$ & $14.8 \operatorname{lux}$ \\
13 & $5.50 \operatorname{lux}$ & $3.10 \operatorname{lux}$ \\
14 & $10.6 \operatorname{lux}$ & $7.90 \operatorname{lux}$ \\
15 & $10.5 \operatorname{lux}$ & $15.9 \operatorname{lux}$ \\
16 & $7.60 \operatorname{lux}$ & $8.50 \operatorname{lux}$ \\
\hline Average & $10.79 \operatorname{lux}$ & $11.66 \operatorname{lux}$ \\
\hline
\end{tabular}

\section{Mathematical Calculation}

In this calculation, the classrooms used to represent MTs Khairul Ummah Islamic Boarding School is class A and to represent MA Khairul Ummah Islamic Boarding School is class B.

- The number of luminaires needed for class A MTs Khairul Ummah Islamic Boarding School using equation 6.

$$
\mathrm{N}=\frac{\mathrm{E} \times \mathrm{A}}{\mathrm{L} \times \mathrm{UF} \times \mathrm{MF}}
$$




\section{$\mathrm{N}=\frac{350 \times 60.86}{3000 \times 0.6599 \times 0.8}=13.6$ Luminaires}

For class A has a number of luminaires needed are 13.61 or was fulfilled to 15 luminaires. Thus by using 15 luminaires, we have achieved a lighting level 385.67 lux.

- The number of luminaires needed for class B MA Khairul Ummah Islamic Boarding School using equation 6.

$$
\begin{aligned}
& \mathrm{N}=\frac{\mathrm{E} \times \mathrm{A}}{\mathrm{L} \times \text { UF } \times \mathrm{MF}} \\
& \mathrm{N}=\frac{350 \times 53.24}{3000 \times 0.6924 \times 0.8}=11.21 \text { Luminaires }
\end{aligned}
$$

For class B MA Khairul Ummah Islamic Boarding School, the number of luminaires needed is 11.21 or was fulfilled to 12 luminaires. Thus by using 15 luminaires, we have achieved a lighting level of 374.55 lux.

After the number of luminaires needed in the classroom has been obtained, the next step is to input the number of luminaires for the classroom in the DIALux Evo 8.1 software.

\section{Simulation Results of DIALux Evo 8.1 Software}

i. Classroom A MTs Khairul Ummah Islamic Boarding School

Class A has a room size of 8.95 meters in length, 6.8 meters in width, and 3.4 meters in height. In figure 1 shows a picture of the existing room and design result on DIALux Evo 8.1.

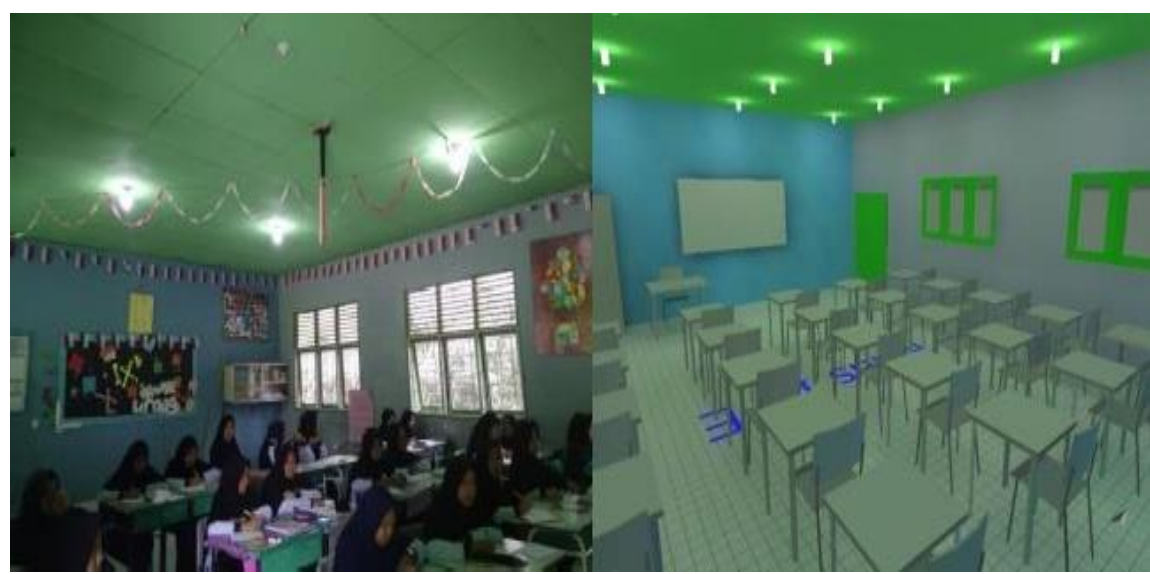

(a)

(b)

Fig. 1: Classroom of A (a) Existing Room. (b) Design on DIALux Evo 8.1

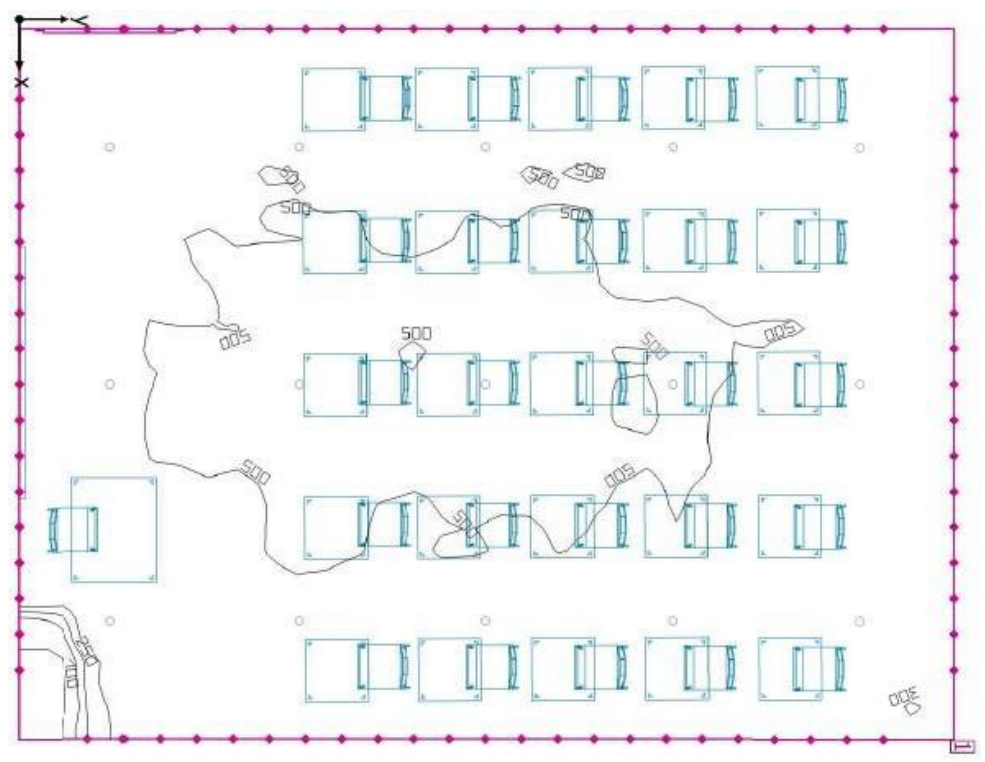

Fig. 2: The Simulation of Class A

In figure 2, the spread of light is quite evenly distributed, so that by using a total of 15 luminaires a lighting level of 388 lux is obtained. In figure 3 is the contour of the diffusion of light in class A output from DIALux Evo 8.1 software. 


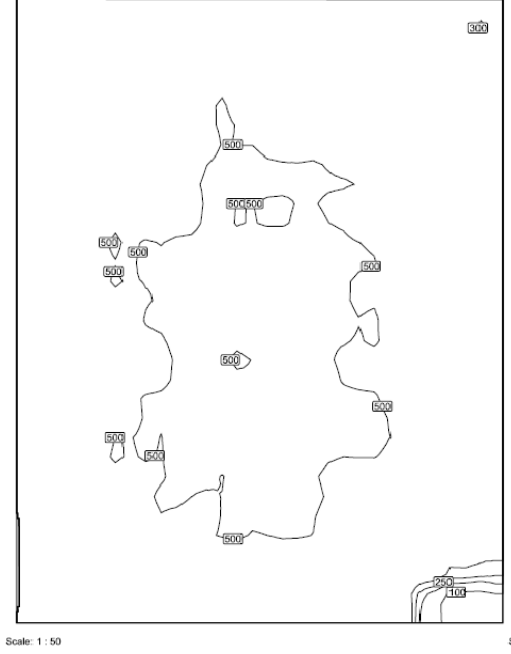

(a)

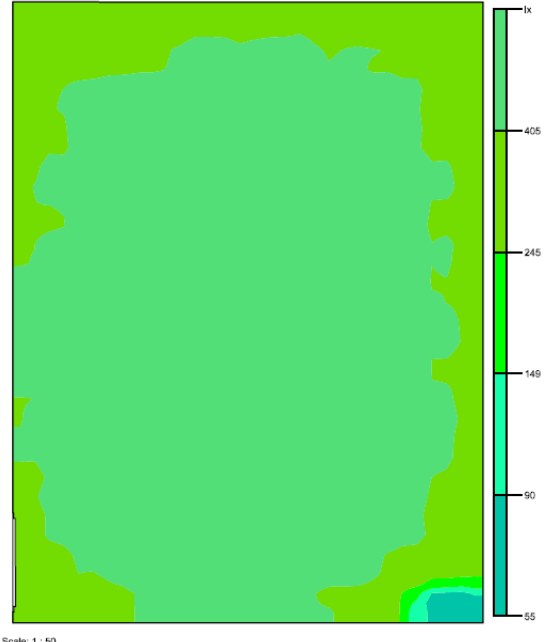

(b)

Fig. 3: Light Distribution Contour in classroom A

(a) Spread line. (b) Difference of color

ii. Classroom B MA Khairul Ummah Islamic Boarding School

Class B has a room size of 7.83 meters in length, 6.8 meters in width, and 2.92 meters in height. In figure 4 is a picture of the existing room and design result on DIALux Evo 8.1.

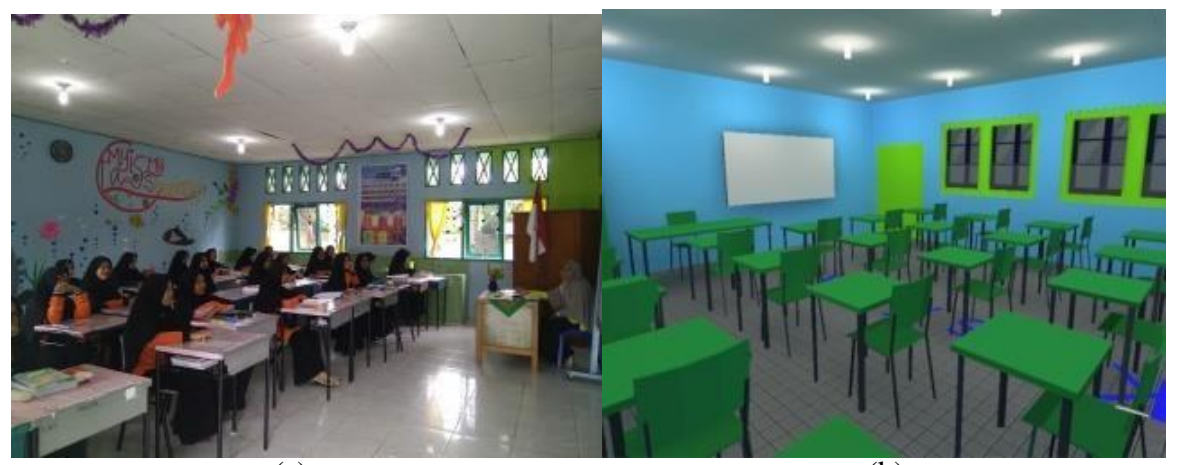

(a)

(b)

Fig. 4: Class B MA Khairul Ummah Islamic Boarding School. (a) Existing Room, (b) Design on DIALux Evo 8.1

The simulation results are shown in figure 5 which is the calculation result in DIALux Evo 8.1 software. In Figure 5 the spread of light is quite evenly distributed, where for the average lighting level value (Average) 362 lux is obtained. Of course with these results, it has reached the minimum lighting level recommended by SNI 6197:2011.

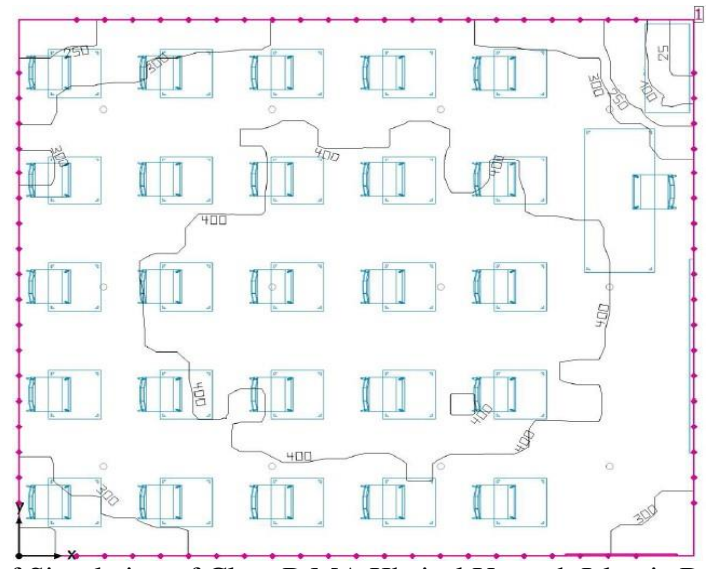

Fig. 5: Result of Simulation of Class B MA Khairul Ummah Islamic Boarding School

Figure 6 is the contour of the spread of light in class B based on lines and color differences. In figure 6(b) the range of views is represented by color, where the color in the middle indicates the value of a high level of lighting, while on the side the cost of the level of light is lower. This is caused by the absorption of light that is not reflected by a surface of the wall in the room so that the light 
reaching the surface of the work plane is different at each point.

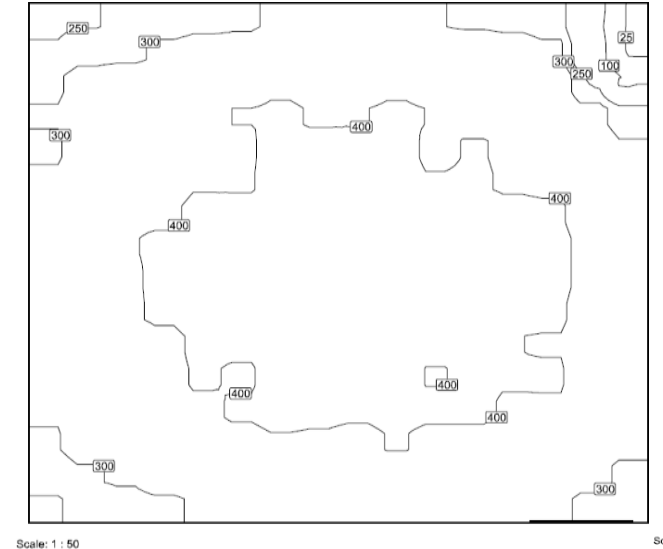

(a)

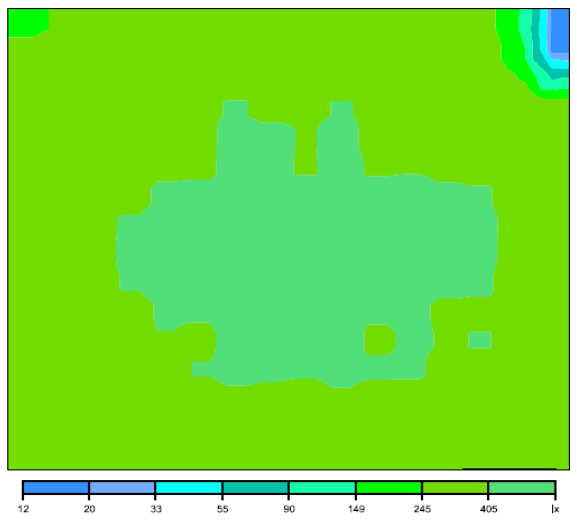

(b)

Fig. 6: Light Distribution Contour in classroom B

(a) Spread line. (b) Difference of color

\section{Comparative Analysis of Calculation Methods}

This sub-chapter explains the comparison of the calculated lighting level values obtained against the standard and percent difference between the two calculations. Based on the calculation result in table 3 for the two-room has exceeded the minimum recommended by SNI 6197:2011.

Table 3: The Comparison of Calculation Results

\begin{tabular}{cccc}
\hline Classroom & $\begin{array}{c}\text { Lighting Level } \\
\text { Recommended } \\
\text { (lux) }\end{array}$ & Lumen & $\begin{array}{c}\text { Calculation Result } \\
\text { (lux) }\end{array}$ \\
\hline A & 350 & 385.67 & $\begin{array}{c}\text { DIALux } \\
\text { Evo 8.1 }\end{array}$ \\
B & & 374.55 & 388 \\
\hline
\end{tabular}

In Table 3 shows the difference in calculation between the lumen method as mathematical calculation and DIALux Evo 8.1 software, were for class A the numerical calculation results get 385.67 lux while on the output of the software of DIALux Evo 8.1 gets the results 388 lux. The difference between the two calculations is $0.6 \%$. Whereas in class B the result of mathematical calculations reaches 374.55 lux, and on the output of the software DIALux Evo 8.1 of 362 lux, so the difference between the two counts is $3.4 \%$. Due to calculation using the lumen method, the surface color is not calculated whereas in the software DIALux Evo 8.1, surface color and type have a role in the calculation process. Figure 7 is a comparison chart of the results of calculations against the standard used for class $\mathrm{A}$ and $\mathrm{B}$.

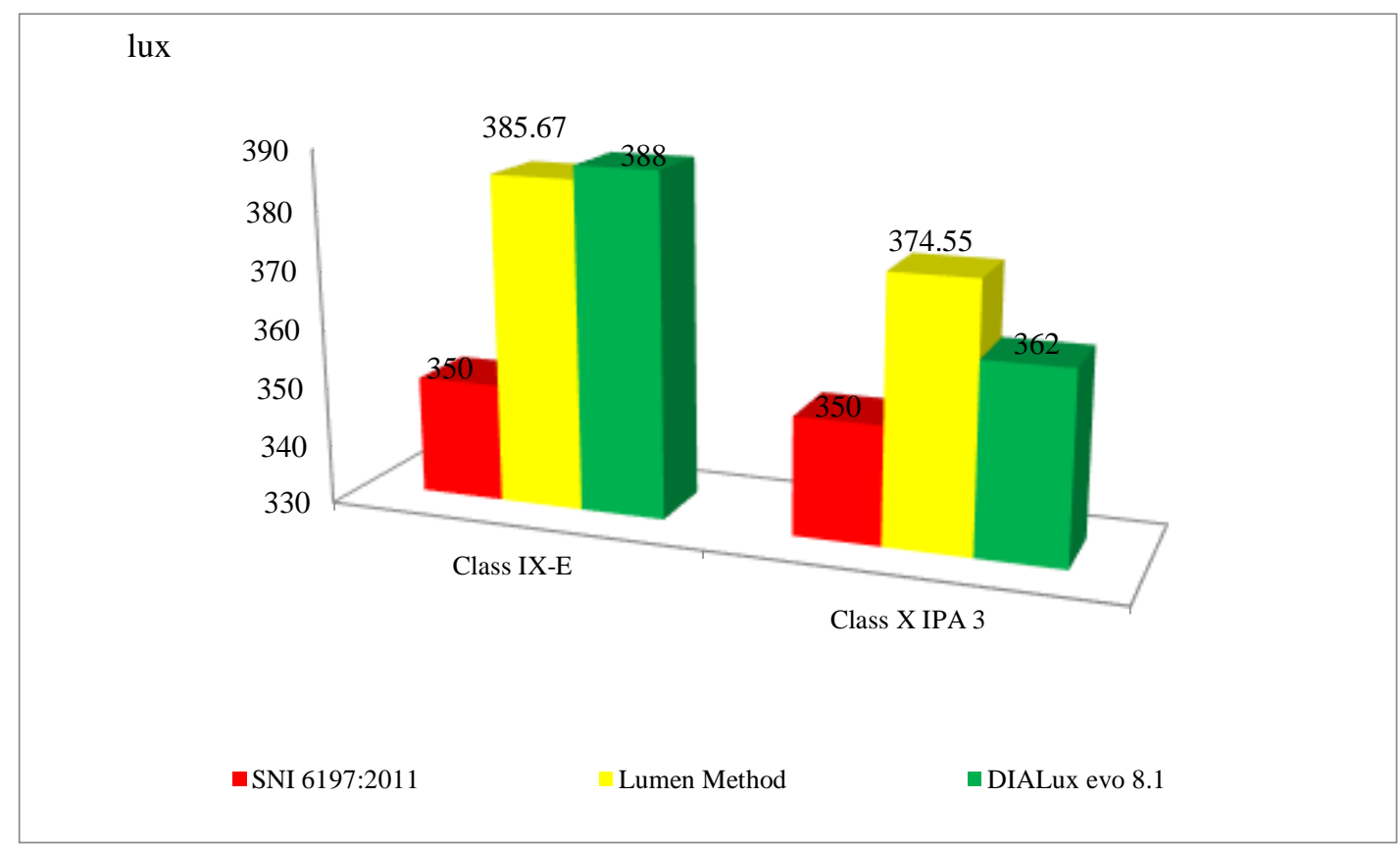

Fig. 7: Comparison Chart of Calculation Results 


\section{CONCLUSION}

Based on the evaluation of lighting quality that has been done on MTs and MA Khairul Ummah Islamic Boarding School, it can be concluded that the lighting system in class A and B has not reached the specified standard, where the value of the direct measurement results of the average lighting level (average) for class A at 10.79 lux and class B at 11.66 lux. To improve lighting conditions that have not reached the minimum recommended standard,it take 15 luminaires for class A and 12 luminaires for B. From the improvement by adding the number of luminaire for each class, the results of mathematical calculations using the lumen method give the results the average lighting for A is 385.67 lux and for class B is 374.55 lux. While the simulation results using DIALux Evo 8.1 software obtained results for class A is 388 lux, and class B is 362 lux. The percentage difference in the calculation results for each room is $0.6 \%$ for class A and 3.4\% for class B. The investment cost needed for two spaces is Rp. 2,700,000.00 to provide 27 lamps of Philips LED bulb $27 \mathrm{~W}$.

\section{ACKNOWLEDGMENT}

\section{REFERENCES}

[1] Dora, P. E, “Optimasi desain pencahayaan ruang kelas SMA Santa Maria Surabaya. . Dimensi Interior, 9(2), 2011,pp 69-79.

[2] Rohadi, R., Sujarwata, S., and Yulianti, I.,"Uji Efektifitas Pencahayaan Ruang Kuliah Menggunakan Software Calculux Indoor 4.12”, Unnes Physics Journal, 6(1), 2017, pp 50-53.

[3] Setyaningsih, E., Wadhani, L., Fat, J., \& Zureidar, I, "Performance of LED Lights installed on DKI Jakarta streets (Case study on Pattimura streets \& Satrio streets, South Jakarta)", Electrical Power, Electronics, Communications, Control, and Informatics Seminar (EECCIS), IEEE, 2014, pp 45-50.

[4] Romadhon, I. F, "Evaluasi Kualitas Penerangan dan Penentuan Letak Lampu serta Jenis Lampu Pada Ruang Perkuliahan E2 Fakultas Teknik Universitas Negeri Semarang", Universitas Negeri Semarang, 2009.

[5] Satwiko, P, "Fisika Bangunan", Yogyakarta: ANDI, 2004.

[6] Harten, P. V., \& Setiawan, E., "Instalasi Listrik Arus Kuat Jilid 2”, Bandung: Percetakan Bina Cipta, 1985.

[7] JH, I. H., \& Anto, B, "Evaluasi Kualitas Pencahayaan pada Ruang Perkuliahaan Gedung C Fakultas Teknik Universitas Riau", Jurnal Online Mahasiswa Fakultas Teknik Universitas Riau, 4(2), 2017, pp 1-5.

[8] Badan Standarisasi Nasional, "SNI 6197-2011: Konservasi Energi Pada Sistem Pencahayaan”, 2011. 